Sauter, Fabian; Klemm, Richard; Gärtner, Claudia; Miethe, Peter; Henze, Stephan; Brückner, Peter; Fütterer, Richard; Becker, Holger:

\title{
Lab-on-a-chip based device for an optical detection of immobilized cells for food analytics
}

Zuerst erschienen in: Biomedical Engineering = Biomedizinische Technik. - Berlin [u.a.] : de Gruyter. - 57 (2012), Suppl. 1, Track-G, p. 719.

Erstveröffentlichung: $\quad$ 2012-08-31

ISSN (online): $\quad$ 1862-278X

ISSN (print): $\quad$ 0013-5585

DOI: $\quad 10.1515 / \mathrm{bmt}-2012-4371$

[Zuletzt gesehen: 2019-08-12]

„Im Rahmen der hochschulweiten Open-Access-Strategie für die Zweitveröffentlichung identifiziert durch die Universitätsbibliothek IImenau."

"Within the academic Open Access Strategy identified for deposition by Ilmenau University Library."

„Dieser Beitrag ist mit Zustimmung des Rechteinhabers aufgrund einer (DFGgeförderten) Allianz- bzw. Nationallizenz frei zugänglich."

"This publication is with permission of the rights owner freely accessible due to an Alliance licence and a national licence (funded by the DFG, German

Research Foundation) respectively." 


\title{
Lab-on-a-Chip based device for an optical detection of immobilized cells for food analytics
}

\author{
F. Sauter ${ }^{1}$, R. Klemm ${ }^{1}$, Dr. C. Gärtner ${ }^{1}$, Dr. P. Miethe ${ }^{2}$, S. Henze ${ }^{2}$, Dr. P. Brückner ${ }^{3}$, R. Fütterer ${ }^{3}$, Dr. H. Becker \\ microfluidic ChipShop GmbH, Jena, Germany (Fabian.Sauter@microfluidic-chipshop.com) \\ 2 fzmb GmbH, Bad Langensalza, Germany \\ 3 TU-Ilmenau, Ilmenau, Germany
}

\section{Introduction}

There is a need for an on-site detection of pathogenic cells within reasonable time by unskilled staff. Due to minimal consumption of reagents, accelerated reaction rates, and completely automated and integrated processes, Lab-on-aChip technology represents an advanced method for the realization of pathogen analysis. This paper described an automated Lab-on-a-Chip based platform for the rapid and reliable detection of Salmonella out of a meat broth.

\section{Methods}

Up to $4.5 \mathrm{~mL}$ of test sample are filtered through a chip-based membrane which is covalently linked with Salmonella specific antibodies. A second fluorescence-marked antibody allows optical detection of the membrane-bound pathogens. A set of valves, reservoirs for buffers and reaction solutions, pump and controller rules the fluidic and biochemical processes inside the chip. The labeled bacteria are identified and counted by applying a high resolution fluorescence camera system. A potential bacterial load is identified by a software-aided analysis of the fluorescent signals.

\section{Results}

The fluidic platform consists of a chip holder and click-on fluidic interfaces facilitating a quick and easily chip replacement. Furthermore the platform assembled with the well attuned actuators, allows a precise progress through of the fluidic scheme provided by the analytic protocol. For the analysis of bacteria in a reasonable concentration the chip was designed with a macro-to-micro interface to enable the handling of up to $4.5 \mathrm{~mL}$ sample volume. The complete assay inclusive different enrichment, washing and labeling steps can be performed within 20 minutes and a detection limit of $10^{\wedge} 3$ bacterial $/ \mathrm{ml}$ can be achieved.

\section{Conclusion}

A fully automated, robust and rapid on-site analysis of potential bacteria contaminating samples is urgently needed for health care reasons but also non-medical requirements. The described platform is a successfully tested tool meeting these specifications and veered toward a high-sensitive and cost-efficient diagnostic device. 